\title{
Impact of the Kuroshio intrusion on the nutrient inventory in the upper northern South China Sea: insights from an isopycnal mixing model
}

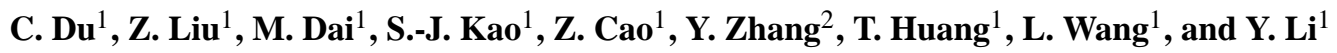 \\ ${ }^{1}$ State Key Laboratory of Marine Environmental Science, Xiamen University, Xiamen 361005, China \\ ${ }^{2}$ Key Laboratory of Coastal Zone Environmental Processes, Yantai Institute of Coastal Zone Research, Chinese Academy of \\ Sciences, Yantai 264003, China \\ Correspondence to: M. Dai (mdai@xmu.edu.cn)
}

Received: 29 March 2013 - Published in Biogeosciences Discuss.: 18 April 2013

Revised: 17 August 2013 - Accepted: 29 August 2013 - Published: 10 October 2013

\begin{abstract}
Based on four cruises covering a seasonal cycle in 2009-2011, we examined the impact of the Kuroshio intrusion, featured by extremely oligotrophic waters, on the nutrient inventory in the central northern South China Sea (NSCS). The nutrient inventory in the upper $100 \mathrm{~m}$ of the water column in the study area ranged from $\sim 200$ to $\sim 290 \mathrm{mmol} \mathrm{m}^{-2}$ for $\mathrm{N}+\mathrm{N}$ (nitrate plus nitrite), from $\sim 13$ to $\sim 24 \mathrm{mmol} \mathrm{m}^{-2}$ for soluble reactive phosphate and from $\sim 210$ to $\sim 430 \mathrm{mmol} \mathrm{m}^{-2}$ for silicic acid. The nutrient inventory showed a clear seasonal pattern with the highest value appearing in summer, while the $\mathrm{N}+\mathrm{N}$ inventory in spring and winter had a reduction of $\sim 13$ and $\sim 30 \%$, respectively, relative to that in summer. To quantify the extent of the Kuroshio intrusion, an isopycnal mixing model was adopted to derive the proportional contribution of water masses from the SCS proper and the Kuroshio along individual isopycnal surfaces. The derived mixing ratio along the isopycnal plane was then employed to predict the genuine gradients of nutrients under the assumption of no biogeochemical alteration. These predicted nutrient concentrations, denoted as $N_{\mathrm{m}}$, are solely determined by water mass mixing. Results showed that the nutrient inventory in the upper $100 \mathrm{~m}$ of the NSCS was overall negatively correlated to the Kuroshio water fraction, suggesting that the Kuroshio intrusion significantly influenced the nutrient distribution in the SCS and its seasonal variation. The difference between the observed nutrient concentrations and their corresponding $N_{\mathrm{m}}$ allowed us to further quantify the nutrient removal/addition associated with the biogeochemical processes on top of the
\end{abstract}

water mass mixing. We revealed that the nutrients in the upper $100 \mathrm{~m}$ of the water column had a net consumption in both winter and spring but a net addition in fall.

\section{Introduction}

The major ocean basins at low latitudes are often nutrient depleted in their upper mixed layer because strong stratification in the pycnocline diminishes nutrient supplies from the depths through diapycnal mixing (Lewis et al., 1986). While coastal oceans are typically characterized by higher nutrient concentrations due to abundant riverine inputs at the surface (e.g., Cai et al., 2004; Chen and Chen, 2006; Han et al., 2012) and elevated supplies from the depths through processes such as strong upwelling and/or enhanced diapycnal mixing (e.g. Bourgault et al., 2011; Gong et al., 1992; Tian et al., 2009), the deep basins of some large marginal seas in low latitudes are overall oligotrophic due partly to the year-round stratification (e.g. Thingstad et al., 2005; Wu et al., 2003). On the other hand, some marginal seas are strongly influenced by the boundary currents of the adjacent open ocean (Chen, 2008; Gordon, 1967; Huertas et al., 2012; Matsuno et al., 2009; Qu et al., 2000) which are usually very oligotrophic. An example is the Kuroshio of the North Pacific Ocean, which is featured by extremely low nutrients. Nutrients within the marginal seas may thus be significantly impacted by permanent or occasional intrusions of the boundary currents. Although the interactions between the open oceans and the marginal seas 


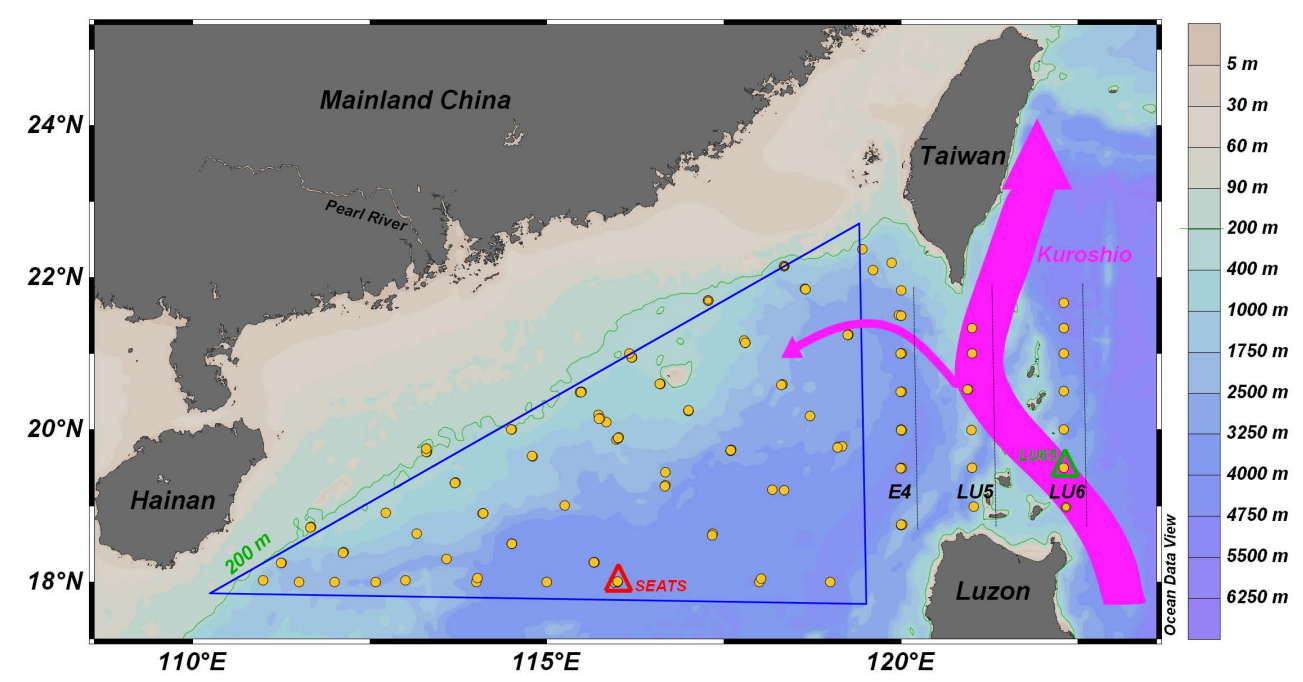

Fig. 1. Map of the northern South China Sea (NSCS) showing its topography and the locations of the sampling stations (yellow dots). The blue triangle indicates the focused region in which the nutrient inventory was assessed. Three meridional sections across the Luzon Strait are highlighted with dark dotted lines (i.e., sections E4, LU5 and LU6, among which sections LU5 and LU6 were investigated only in spring 2011). Also shown schematically are the Kuroshio Current and its intrusion path into the NSCS around the Luzon Strait (pink lines). The South East Asian Time-series Study (SEATS) station (red triangle) is established in the central basin of the SCS, while station LU65 (green triangle) is located in the Kuroshio travel path.

have been extensively studied in terms of their water exchanges and the dynamic controls (e.g. Baringer et al., 1999; Chu and Li, 2000; Hu et al., 2000; Kida et al., 2009; Liang et al., 2008; Matsuno et al., 2009; Partt and Spall, 2008; Qu et al., 2000; Shaw, 1991; Tian et al., 2006), their impacts on the nutrient inventory of the marginal seas and the consequent biogeochemical effects have rarely been examined (Huertas et al., 2012).

The South China Sea (SCS) is the largest marginal sea of the Pacific. The basin area of the SCS is characterized by nutrient deficiency in its surface and thus very low primary productivity. The SCS is also under significant modulation by water exchanges through the Luzon Strait. It is well known that the Kuroshio carries the most oligotrophic water of the world's oceans and that it intrudes into the SCS at least in winter (e.g. Centurioni et al., 2004; Chen et al., 2001; Chu and Li, 2000; Hu et al., 2000; Qu, 1999; Qu et al., 2000). However, the impact of the Kuroshio intrusion on the upper ocean nutrient inventory, or the depth-integrated nutrient concentration in the SCS has rarely been assessed in a quantitative way.

In this study, a large data set of nutrients including $\mathrm{N} / \mathrm{P} / \mathrm{Si}$ was collected during four cruises to the northern SCS (NSCS) covering a complete seasonal cycle. The upper $100 \mathrm{~m}$ nutrient inventory, which ultimately determines the primary productivity in each season was calculated and compared. Moreover, an isopycnal mixing model was developed to quantitatively estimate the seasonal intrusion pattern of the Kuroshio to the NSCS. Based on a combination of field observations and the model calculation, the Kuroshio's influ- ence on the upper $100 \mathrm{~m}$ nutrient inventory of the NSCS was further quantified and the biogeochemical processes on top of the isopycnal mixing were examined.

\section{Materials and methods}

\subsection{Study area}

The seasonally reversing East Asian Monsoon drives a clockwise circulation in summer and partially anticlockwise circulation during winter in the upper SCS (Wu et al., 2003). As a consequence, the interior of the SCS is effectively isolated from terrestrial inputs and forms a basin-wide gyre, which displays overall oligotrophic characteristics similar to those in the major ocean basins (Gong et al., 1992). On the other hand, the SCS and the western North Pacific (wNP) exchange their water masses via the 2200 m-deep Luzon Strait, through which the Kuroshio Branch Water intrudes from the wNP into the SCS (Chen, 2001; Chu and Li, 2000; Dai et al., 2009; Hu et al., 2000; Qu et al., 2000) (Fig. 1). It is reported that at the salinity maximum layer, at a depth of $\sim 150 \mathrm{~m}$, the Kuroshio intrudes into the SCS all year round (Qu et al., 2000).

\subsection{Sampling and analyses}

Field observations were carried out in summer (JulyAugust 2009), winter (January 2009), fall (OctoberNovember 2010) and spring (May 2011). The sampling area covered nearly the entire NSCS except in the fall cruise when 
only the western part of the NSCS was covered due to high sea conditions. In this study, we focused on the central NSCS covering a region from 111 to $119.5^{\circ} \mathrm{E}$ and from $17.7^{\circ} \mathrm{N}$ to roughly the $200 \mathrm{~m}$ isobaths in the meridional direction (Fig. 1). The total surface area of the subject zone is about $2.74 \times 10^{11} \mathrm{~m}^{2}$. We excluded the shelf shallower than $200 \mathrm{~m}$ (Fig. 1) where the nutrient inventories are under significant influence of the riverine inputs.

Nutrient samples were collected with a Rosette sampler at $5,25,50,75$ and $100 \mathrm{~m}$ layer in the upper $100 \mathrm{~m}$, and analysed onboard using a Four-channel Continuous Flow Technicon AA3 Auto-Analyzer (Bran-Lube GmbH). The detection limits for $\mathrm{N}+\mathrm{N}$ (nitrate plus nitrite), SRP (soluble reactive phosphate) and $\mathrm{Si}(\mathrm{OH})_{4}$ (silicic acid) were $0.03 \mu \mathrm{mol} \mathrm{L}^{-1}, 0.03 \mu \mathrm{mol} \mathrm{L}^{-1}$ and $0.05 \mu \mathrm{mol} \mathrm{L}^{-1}$, respectively. The analytical precision was better than $\pm 1 \%$ for $\mathrm{N}+\mathrm{N}, \pm 2 \%$ for SRP and $\pm 2.8 \%$ for $\mathrm{Si}(\mathrm{OH})_{4}$ (Han et al., 2012). In addition, SRP was determined at nanomolar levels in the surface waters. The SRP in the water samples was pre-concentrated as phosphomolybdenum blue into a solid phase cartridge (Waters Oasis), then eluted with sodium hydroxide solution, and finally determined using a spectrophotometer within a flow injection system. The detection limit of this method is $1.4 \mathrm{nmol} \mathrm{L}^{-1}$ and the precision is better than $\pm 5 \%$ (Ma et al., 2008; Han et al., 2012). Depth profiles of temperature and salinity were determined shipboard with a SBE 911 plus conductivity-temperature-depth (CTD) profiler (Sea-Bird Inc).

\subsection{Estimation of the nutrient inventory}

Using field measured nutrient concentrations, we estimated both the station-integrated and area-integrated nutrient inventories in the central NSCS. The former was calculated by integrating nutrient concentrations in the upper $100 \mathrm{~m}$ of the water column at individual stations. The latter was obtained by integrating the station-integrated nutrient inventory over the entire study area via spatial interpolations, for which the Inverse Distance Square method was applied (Lin et al., 2002).

\section{Results}

\subsection{Hydrography}

As shown in Fig. 2, the potential temperature-salinity $(\theta-S)$ distributions in the upper $400 \mathrm{~m}$ of the water column revealed a distinct hydrological difference between the central NSCS and the Kuroshio, with the latter being indicated by data points collected along sections LU5 and LU6. At density levels of $<1025.7 \mathrm{~kg} \mathrm{~m}^{-3}$, which corresponded to the depth of $<200 \mathrm{~m}$ in the NSCS and $<350 \mathrm{~m}$ in the Kuroshio, the Kuroshio water tended to have higher potential temperature and salinity than the SCS water at the same isopycnal layer. However, the pattern was reversed at greater depths

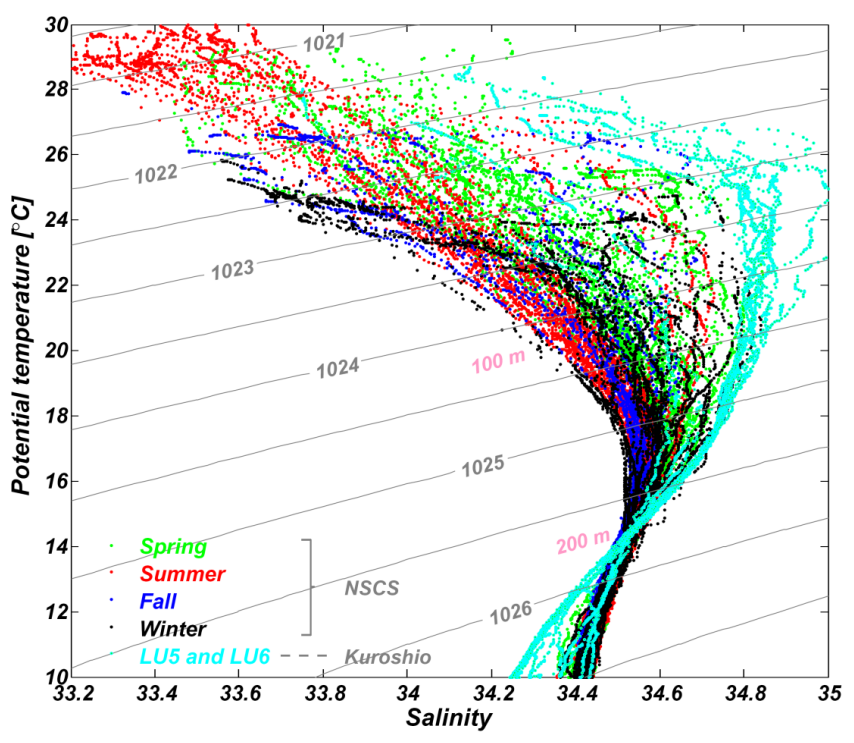

Fig. 2. Potential temperature $(\theta)$ versus salinity $(S)$ plots $(\theta-S$ diagram) in the upper $400 \mathrm{~m}$ of the water column for the sampling stations in the central northern South China Sea (NSCS) during four seasons and along sections LU5 and LU6 in spring. Also marked are the depths of $100 \mathrm{~m}$ (density $1024.2 \mathrm{~kg} \mathrm{~m}^{-3}$ ) and $200 \mathrm{~m}$ (density $1025.6 \mathrm{~kg} \mathrm{~m}^{-3}$ ) in the central NSCS.

(Fig. 2). Among the four seasons, the summer $\theta$-S distribution pattern in the central NSCS was least close to that of the Kuroshio water, and the data points in the upper $200 \mathrm{~m}$ in summer were overall less scattered relative to those during spring, fall and winter, due likely to the higher extent of the Kuroshio intrusion in the latter three seasons. At density levels of $>1026.2 \mathrm{~kg} \mathrm{~m}^{-3}$ (corresponding to the depth of $>300 \mathrm{~m}$ in the NSCS), no significant seasonal variations of $\theta-S$ distributions were observed in the central NSCS.

It is known that the Kuroshio intrusion can be down to $400 \mathrm{~m}$ (Fang et al., 2009; Tian et al., 2006). We focused on the nutrient dynamics in the upper $100 \mathrm{~m}$ of the central NSCS since biological alterations of nutrients are highest in the euphotic zone, which typically extends from the surface to $\sim 100 \mathrm{~m}$ water depth in the SCS (Chen et al., 2008; Tseng et al., 2005) where any changes in nutrients would profoundly result in changes in primary productivity of the ecosystem.

\subsection{Nutrient distribution in the upper $100 \mathrm{~m}$ of the central NSCS and the Kuroshio}

Since the distribution patterns of N $+N$, SRP and $\mathrm{Si}(\mathrm{OH})_{4}$ were similar, we used $\mathrm{N}+\mathrm{N}$ as an example throughout this paper unless otherwise indicated. The spatial and temporal distributions of the iso-depth $\mathrm{N}+\mathrm{N}$ concentration are shown in Fig. 3. During spring and summer, the surface $\mathrm{N}+\mathrm{N}$ concentration in the entire central NSCS was mostly below the detection limit of quantification, or $<0.1 \mu \mathrm{mol} \mathrm{L}^{-1}$ (Fig. 3a, b). Similarly in fall, the surface $\mathrm{N}+\mathrm{N}$ concentrations at the 

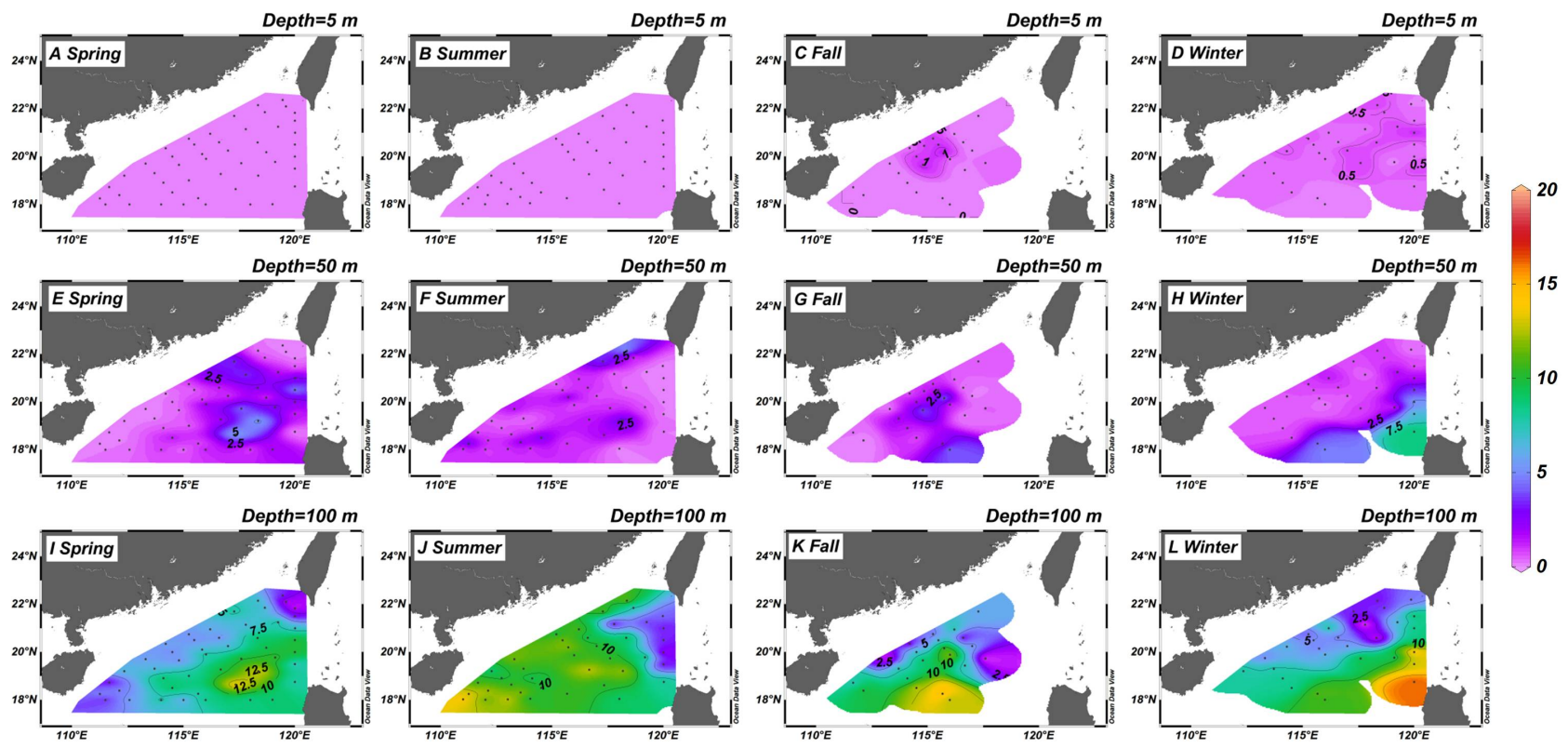

Fig. 3. Iso-depth distributions of $\mathrm{N}+\mathrm{N}$ (nitrate plus nitrite, $\mu \mathrm{mol} \mathrm{L}{ }^{-1}$ ) concentrations at depths of $5 \mathrm{~m}(\mathbf{A}-\mathbf{D}), 50 \mathrm{~m}(\mathbf{E}-\mathbf{H})$ and $100 \mathrm{~m}(\mathbf{I}-\mathbf{L})$ in the central northern South China Sea and Kuroshio during the four seasons (spring: A, $\mathbf{E}$ and $\mathbf{I}$; summer: $\mathbf{B}, \mathbf{F}$ and $\mathbf{J}$; fall: $\mathbf{C}, \mathbf{J}$ and $\mathbf{K}$; winter: D, $\mathbf{H}$ and $\mathbf{L}$ ).

majority of the sampling stations were below the detection limit, except at the four stations located in the central basin, which displayed a relatively high $\mathrm{N}+\mathrm{N}$ concentration of $\sim 1.5 \mu \mathrm{mol} \mathrm{L}^{-1}$ (Fig. 3c). This region was characterized by low sea surface temperature (data not shown), possibly indicating that the potentially strong wind-driven vertical mixing and/or upwelling processes in fall drew nutrient-rich waters from the depths. In winter, the surface $\mathrm{N}+\mathrm{N}$ concentration ranged $0-1.2 \mu \mathrm{mol} \mathrm{L}^{-1}$, which was slightly higher than that in other seasons (Fig. 3d).

Nutrient concentrations increased rapidly with depth as shown in Fig. 3e-l. During spring, high nutrient centers with $\mathrm{N}+\mathrm{N}>2 \mu \mathrm{mol} \mathrm{L}{ }^{-1}$ and $>10 \mu \mathrm{mol} \mathrm{L}^{-}$were observed at $50 \mathrm{~m}$ (Fig. 3e) and $100 \mathrm{~m}$ (Fig. 3i), respectively, in the central part of the NSCS. In this region, low temperature and high salinity (data not shown) were observed at 75 and $100 \mathrm{~m}$, and sea surface height also had low values in the same region, which indicated that a cyclonic circulation occurred in this region, and might have induced this high $\mathrm{N}+\mathrm{N}$ center. In summer, $\mathrm{N}+\mathrm{N}$ distributions showed significant spatial variations in the central NSCS, with higher concentrations in the western part $\left(>1 \mu \mathrm{mol} \mathrm{L}^{-1}\right.$ at $50 \mathrm{~m}$ and $>10 \mu \mathrm{mol} \mathrm{L}^{-1}$ at $100 \mathrm{~m})$ and lower ones in the eastern part $\left(<1 \mu \mathrm{mol} \mathrm{L}^{-1}\right.$ at $50 \mathrm{~m}$ and $<10 \mu \mathrm{mol} \mathrm{L}^{-1}$ at $100 \mathrm{~m}$ ) (Fig. 3f, j). During fall, $\mathrm{N}+\mathrm{N}$ concentrations at $50 \mathrm{~m}$ were relatively higher in the middle and southern regions $\left(>2 \mu \mathrm{mol} \mathrm{L}^{-1}\right)$ than those in the western and eastern regions $\left(<1 \mu \mathrm{mol} \mathrm{L}{ }^{-1}\right)$ of the NSCS (Fig. 3g). At $100 \mathrm{~m}$ however, higher values were observed in the western part $\left(\sim 10 \mu \mathrm{mol} \mathrm{L}^{-1}\right)$ while lower values were observed in the eastern part $\left(<5 \mu \mathrm{mol} \mathrm{L}^{-1}\right)$ (Fig. $\left.3 \mathrm{k}\right)$. In winter, a broad zone with low nutrient levels was located along the shelf break, corresponding to an $\mathrm{N}+\mathrm{N}$ concentration of $0-2 \mu \mathrm{mol} \mathrm{L}^{-1}$ at $50 \mathrm{~m}$ (Fig. 3h) and $2-10 \mu \mathrm{mol} \mathrm{L}^{-1}$ at $100 \mathrm{~m}$ (Fig. 31). Meanwhile, a high $\mathrm{N}+\mathrm{N}$ concentration zone was observed along section E4 in the northeast part of the NSCS (Fig. 3h, 1).

\subsection{Comparison of nutrient distributions between the central NSCS and the Kuroshio waters}

Vertical distributions of potential temperature and SRP in the upper $200 \mathrm{~m}$ at the SEATS (South East Asian Time-series Study, Wong et al., 2007) and LU65 stations, which were representative of the SCS and Kuroshio waters, respectively, are shown in Fig. 4. Here only the SRP was shown because we did not have enough data of $\mathrm{N}+\mathrm{N}$ at low level in the upper nutricline to draw comparison between seasons. Significant seasonal patterns were observed at the SEATS station. Its upper mixed layer depth (MLD, optimal estimation of $\Delta T=0.8^{\circ} \mathrm{C}$ according to Kara et al., 2000) was deeper in winter $(\sim 60 \mathrm{~m})$ than in spring $(\sim 10 \mathrm{~m})$, summer $(\sim 35 \mathrm{~m})$ and fall $(\sim 40 \mathrm{~m})$ (Fig. $4 \mathrm{a})$. On the other hand, SRP concentrations in the mixed layer were higher in fall $\left(\sim 0.08 \mu \mathrm{mol} \mathrm{L}^{-1}\right)$ than those in spring $\left(\sim 0.04 \mu \mathrm{mol} \mathrm{L}^{-1}\right)$, summer $\left(\sim 0.02 \mu \mathrm{mol} \mathrm{L}^{-1}\right)$ and winter $\left(\sim 0.03 \mu \mathrm{mol} \mathrm{L}^{-1}\right)$ (Fig. 4b). At the same depth above $200 \mathrm{~m}$, the Kuroshio water was relatively warmer by $0-8^{\circ} \mathrm{C}$ and the SRP lower by $0-1.1 \mu \mathrm{mol} \mathrm{L}^{-1}$ than the SCS water. In this context, intrusions of the Kuroshio water with low nutrient content might have induced a dilution effect on the NSCS nutrients. 
Table 1. Summary of the area-integrated nutrient inventories in the upper $100 \mathrm{~m}$ of the water column in the central northern South China Sea.

\begin{tabular}{lcccccc}
\hline \multirow{2}{*}{ Seasons } & \multicolumn{3}{c}{ Inventory $\left(10^{9} \mathrm{~mol}\right)$} & \multicolumn{3}{c}{ Reduction relative to summer (\%) } \\
& $\mathrm{N}+\mathrm{N}$ & $\mathrm{SRP}$ & $\mathrm{Si}(\mathrm{OH})_{4}$ & $\mathrm{~N}+\mathrm{N}$ & $\mathrm{SRP}$ & $\mathrm{Si}(\mathrm{OH})_{4}$ \\
\hline Spring & 69 & 5.8 & 106 & 13.2 & 10.8 & 10.1 \\
Summer & 80 & 6.5 & 118 & - & - & - \\
Fall & 67 & 6.2 & 98 & 16.2 & 5.7 & 17.1 \\
Winter & 55 & 3.6 & 58 & 31.7 & 44.4 & 51.0 \\
\hline
\end{tabular}
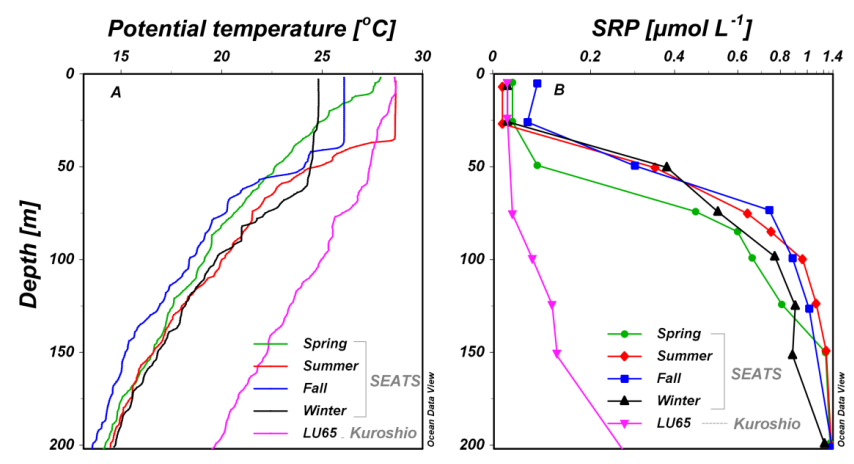

Fig. 4. Vertical distribution of potential temperature (A) and SRP (soluble reactive phosphate, (B)) in the upper $200 \mathrm{~m}$ of the water column at the SEATS station in different seasons and station LU65 in spring.

It should be pointed out that the MLD $(\sim 60 \mathrm{~m})$ in winter was deeper than the top of nutricline (TND, $\sim 50 \mathrm{~m})$, and it was consistent with the previous observations at the SEATS station (Tseng et al., 2005, 2007). Such a decoupling may be a result of the combination of the physical dynamics and biological alteration. Firstly, it can be attributable to the uneven consumption rate of nutrients by biological metabolism vs. water depth within the mixed layer because of the light intensity differences. Secondly, it can also be related to the definition of the MLD. Here we defined the MLD with temperature difference $(\Delta T)$ from the sea surface temperature, and a critical value of $0.8^{\circ} \mathrm{C}$ was adopted (Kara et al., 2000). This definition of MLD might not be sensitive enough at times to catch for example weak stratification that would diminish the mixing within the upper layer. Finally, it should also be pointed out that the coarse sampling resolution of our discrete nutrient samples also made it difficult to precisely estimate the depth of TND.

\subsection{Nutrient inventory in the upper $100 \mathrm{~m}$ of the central NSCS}

The station-integrated $\mathrm{N}+\mathrm{N}$ inventory in the upper $100 \mathrm{~m}$ of the central NSCS is shown in Fig. 5. The $\mathrm{N}+\mathrm{N}$ inventory ranged from $50-600 \mathrm{mmol} \mathrm{m}^{-2}$ in spring (Fig. 5a). A high $\mathrm{N}+\mathrm{N}$ inventory center of $>500 \mathrm{mmol} \mathrm{m}^{-2}$ was observed in the central basin of the NSCS, which was about twice that at the edge stations $\left(\sim 100-200 \mathrm{mmol} \mathrm{m}^{-2}\right)$. Regions with the $\mathrm{N}+\mathrm{N}$ inventory $<100 \mathrm{mmol} \mathrm{m}^{-2}$ were observed at the northeast part near Taiwan and the southwest part near Hainan. During summer (Fig. 5b), the station-integrated $\mathrm{N}+\mathrm{N}$ inventory was mostly $>300 \mathrm{mmol} \mathrm{m}^{-2}$ in the entire central NSCS, whereas the $<100 \mathrm{mmol} \mathrm{m}^{-2}$ region was observed only at the western part. In fall, the $\mathrm{N}+\mathrm{N}$ inventory was higher in the western part $\left(>300 \mathrm{mmol} \mathrm{m}^{-2}\right)$, but lower in the eastern part $\left(<100 \mathrm{mmol} \mathrm{m}^{-2}\right)$ (Fig. 5c). During winter, a band with low $\mathrm{N}+\mathrm{N}$ inventory $\left(<200 \mathrm{mmol} \mathrm{m}^{-2}\right)$ was located between the Luzon Strait and $115^{\circ} \mathrm{E}$ along the shelf break in the northeast part of the central NSCS (Fig. 5d), in which an extremely low $\mathrm{N}+\mathrm{N}$ inventory center $\left(\sim 20 \mathrm{mmol} \mathrm{m}^{-2}\right)$ was observed. Combined with the isodepth distributions (Fig. 3), the $\mathrm{N}+\mathrm{N}$ inventory results revealed an overall pattern that the nutrients were consistently higher in the western than in the eastern part of the central NSCS.

On the basis of these seasonal observations, the annual averaged $\mathrm{N}+\mathrm{N}$ inventory was estimated to be $\sim 250 \mathrm{mmol} \mathrm{m}^{-2}$ in the central NSCS, which was significantly higher than that in the Kuroshio in spring, implying again the potential dilution effect of the Kuroshio intrusion on the nutrient inventory of the upper NSCS.

Taking the central NSCS as a whole, the area-integrated $\mathrm{N}+\mathrm{N}$ inventory (see Sect. 2.3 for details) was highest in summer, while it was $\sim 13, \sim 16$ and $\sim 32 \%$ lower in spring, fall and winter, respectively, as compared to that in summer (Table 1). The seasonal patterns of the SRP and $\mathrm{Si}(\mathrm{OH})_{4}$ inventories were similar to that of $\mathrm{N}+\mathrm{N}$ but with larger degrees of reduction in winter as compared to $\mathrm{N}+\mathrm{N}$ (Table 1).

\section{Discussion}

\subsection{Water fraction estimation with the isopycnal mixing approximation}

In exploring the seasonal intrusions of the Kuroshio to the central NSCS, we assumed that the mixing between different water masses was mainly along isopycnal surfaces, while the diapycnal processes which occurred were insignificant. This statement can be approached by means of a comparison between the diffusive flux along and across isopycnal surfaces. 

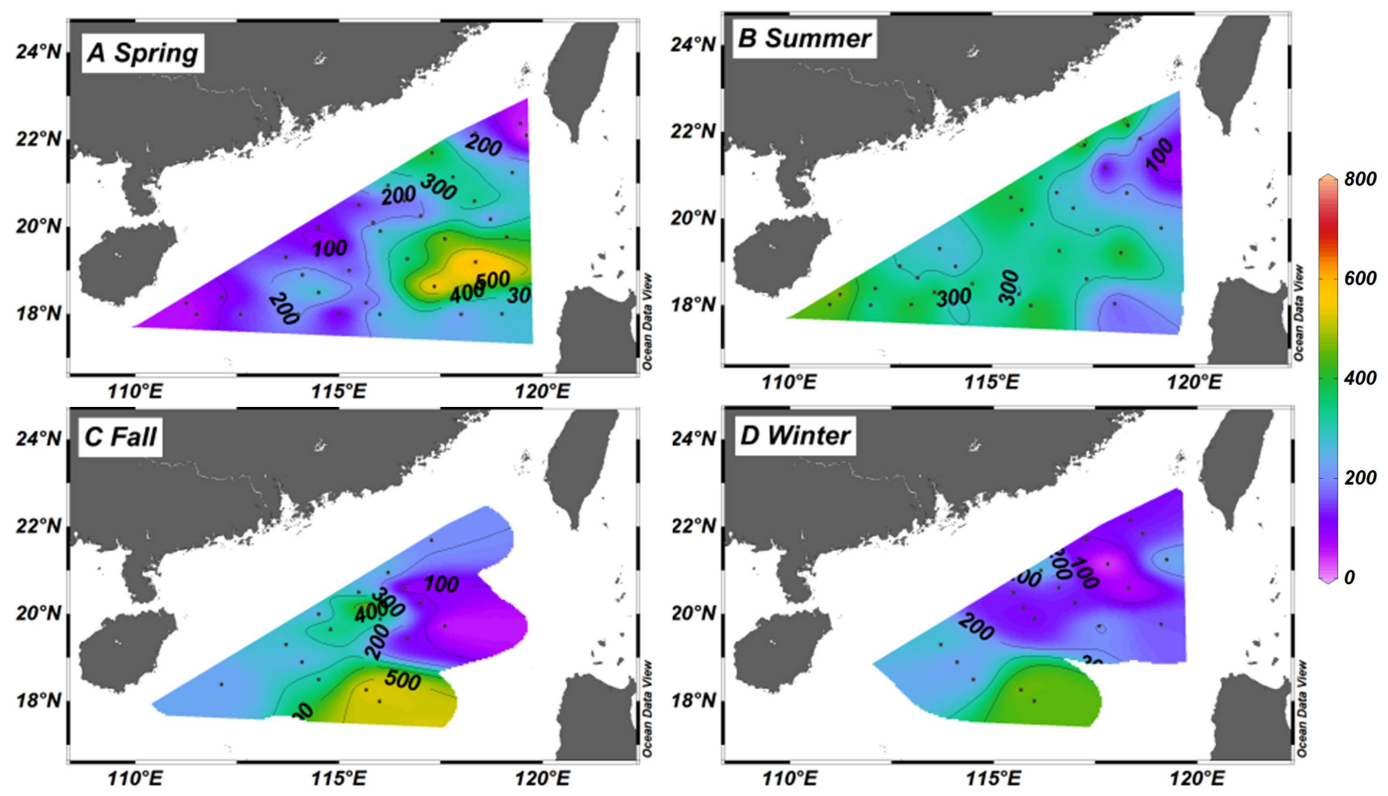

Fig. 5. Station-integrated $\mathrm{N}+\mathrm{N}$ inventory $\left(\mathrm{mmol} \mathrm{m}^{-2}\right)$ in the upper $100 \mathrm{~m}$ of the water column in the central northern South China Sea. (A) spring; (B) summer; (C) fall; and (D) winter.
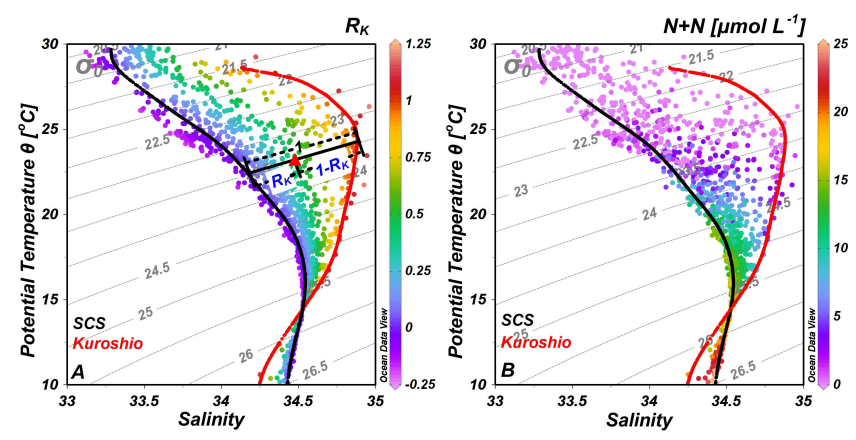

Fig. 6. Potential temperature $(\theta)$ versus salinity $(S)$ plots $(\theta-S$ diagram) in the upper $400 \mathrm{~m}$ of the water column for the sampling stations in the central northern South China Sea (NSCS) superimposed by (A) the isopycnal mixing model-derived Kuroshio water fraction $\left(R_{\mathrm{K}}\right)$, and $(\mathbf{B})$ the field observed $\mathrm{N}+\mathrm{N}$ (nitrate plus nitrite) concentrations. A red triangle in (A) donates an example of the $R_{\mathrm{K}}$ calculation along the potential density 1023.5 surface. Data of the typical Kuroshio water were collected from LU6 section in spring, while data of the SCS proper water were collected from station SEATS and its nearby stations in summer.

According to Fick's law of diffusion, the diffusive flux of dissolved material can be expressed as

$F=-K \times \partial c / \partial x$,

where $K$ can be either the diapycnal $\left(K_{\mathrm{V}}\right)$ or isopycnal $\left(K_{\mathrm{H}}\right)$ diffusivity, and $\partial c / \partial x$ is the corresponding concentration gradient. Here we take $100 \mathrm{~m}$ as an example. Note that the results of the other layers in the upper $100 \mathrm{~m}$ resemble that of the $100 \mathrm{~m}$. We adopted the $K_{\mathrm{V}}$ of $10^{-5} \mathrm{~m}^{2} \mathrm{~s}^{-1}$ according to Liu and Lozovatsky (2012) and the $K_{\mathrm{H}}$ of $500 \mathrm{~m}^{2} \mathrm{~s}^{-1}$ based on Glover et al. (2005). The horizontal gradient in $\mathrm{N}+\mathrm{N}$ was $\sim 1.0 \times 10^{-5} \mathrm{mmol} \mathrm{m}^{-4}$ based on the estimated distance of $750 \mathrm{~km}$ and a concentration difference of about $10 \mathrm{mmol} \mathrm{m}^{-3}$ in $\mathrm{N}+\mathrm{N}$ between section LU6 of the Kuroshio and the central NSCS. At the same time, the vertical gradient in $\mathrm{N}+\mathrm{N}$ at the SEATS station was estimated to be $\sim 1.0 \times 10^{-1} \mathrm{mmol} \mathrm{m}^{-4}$ at the $100 \mathrm{~m}$ layer. Based on Eq. (1), the along isopycnal flux was estimated to be $5.0 \times 10^{-3} \mathrm{mmol} \mathrm{m}^{-2} \mathrm{~s}^{-1}$, which was three orders of magnitude larger than the diapycnal flux of $1.0 \times 10^{-6} \mathrm{mmol} \mathrm{m}^{-2} \mathrm{~s}^{-1}$. This suggested that isopycnal mixing was indeed prevailing over diapycnal diffusion in controlling the diffusive transport of nutrients in the upper central NSCS.

The mixing ratio of the Kuroshio water and the SCS proper water along any isopycnal surface can be quantitatively determined, the detailed methodology of which can be illustrated with reference to the $\theta-S$ diagram (Fig. 6). Firstly, following previous studies (e.g. Chen and Huang 1996; Gong et al., 1992), the two endmembers representing typical Kuroshio water and SCS proper water were chosen as the precursors of the NSCS water under consideration. For any in situ observed water parcel represented by a point in the $\theta-S$ diagram, the fractional contributions of Kuroshio and SCS water can be derived by adopting the conservative along-isopycnal mixing law of $\theta$ or $S$ :

$$
\begin{aligned}
& R_{\mathrm{K}}=R_{\mathrm{K}_{\theta}}=\frac{\theta-\theta_{\mathrm{S}}}{\theta_{\mathrm{K}}-\theta_{\mathrm{S}}} \\
& R_{\mathrm{K}}=R_{\mathrm{K}_{S}}=\frac{S-S_{\mathrm{S}}}{S_{\mathrm{K}}-S_{\mathrm{S}}} .
\end{aligned}
$$


Here, the Kuroshio water fraction is denoted as $R_{\mathrm{K}}\left(R_{K_{\theta}}\right.$ and $R_{K_{S}}$ represent results derived from $\theta$ and $S$, respectively), and thus $1-R_{\mathrm{K}}$ stands for the SCS proper water fraction. $\theta_{\mathrm{K}}$ and $S_{\mathrm{K}}$ denote the endmember values of $\theta$ and $S$ for the Kuroshio water, while $\theta_{\mathrm{S}}$ and $S_{\mathrm{S}}$ represent those for the SCS proper water. Due to the fact that the thermal structures in the upper ocean are significantly influenced by the seasonally varying heat flux (Tseng et al., 2005), we used $S$ conservation for the upper $60 \mathrm{~m}$ of the water column for model prediction. At greater depths, $\theta$ was used due to its higher sensitivity than salinity (Fig. 6a). It should be pointed out that in the upper ocean, in particular in the mixed layer, the definition of an isopycnal is not easy. We contend that the mixed layer is roughly characterized by uniform $\theta$ and $S$, thus, being representative of a single point in $\theta$-S diagram regardless its thickness. Accordingly, the same mixing ratio will be obtained through our isopycnal model for this mixed layer, which would thus be subject to greater uncertainties because this layer is also affected by the surface heat fluxes that we do not take into account in our calculations. Our approach by using $S$ conservation for the upper $60 \mathrm{~m}$ the water column model prediction should have helped in this regard. We have also vigorously estimated as elaborated in the later discussion sections, individual source terms in our model prediction. Indeed, our uncertainty test using conservative $\mathrm{Ca}^{2+}$ data was able to well validate the model prediction.

The model-derived $R_{\mathrm{K}}$ at each sampling point in the upper $400 \mathrm{~m}$ of the central NSCS is shown in Fig. 6a. As an example, $R_{\mathrm{K}}$ for a water parcel located at the potential density anomaly surface of 23.50, is also shown in Fig. 6a. According to the isopycnal mixing approximation, this water parcel was a mixture of the SCS endmember and the Kuroshio endmember with the same potential density of 23.50 (due to the nonlinear nature of density mixing the genuine potential density anomaly of its parents are slightly higher than 23.50). As such, $R_{\mathrm{K}}$ was estimated to be 0.4 , meaning that the proportional contribution from the Kuroshio was $40 \%$, while the SCS endmember contributed $60 \%$ to the mixture.

We also note that some data beyond the endmembers appeared in Fig. 6. This reflects the difficulty in finding a perfect Kuroshio (or SCS) endmember from the existing observations with $\theta / S$ as well as chemical parameter measurements. Some shelf stations presumably under evident influence of nearshore water masses were excluded from the analysis. The error resulted from the endmember selection is detailed in Sect. 4.2. As shown in Fig. 6b, there was an alongisopycnal surface difference of $\sim 0-10 \mu \mathrm{mol} \mathrm{L}^{-1}$ in $\mathrm{N}+\mathrm{N}$ in the upper $100 \mathrm{~m}$ of the water column between the typical SCS and the Kuroshio. With the derived water fractions, the nutrient concentrations $\left(N_{\mathrm{m}}\right)$ of each water parcel in the central NSCS could be calculated from

$N_{\mathrm{m}}=R_{\mathrm{K}} \times N_{\mathrm{K}}+\left(1-R_{\mathrm{K}}\right) \times N_{\mathrm{S}}$.

This is the nutrient concentration solely due to conservative physical mixing of the parent waters. In situ-observed con-
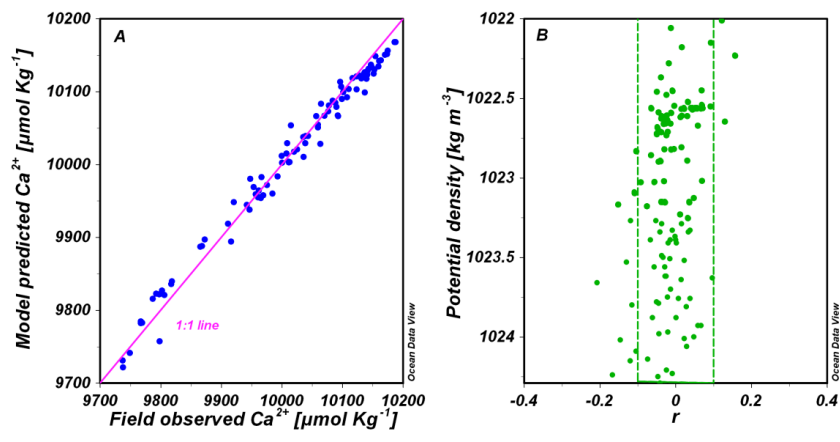

Fig. 7. (A) Scatter plot of the isopycnal mixing predicted $\mathrm{Ca}^{2+}$ and the field observed $\mathrm{Ca}^{2+}$ in the upper $100 \mathrm{~m}$ of the central NSCS. (B) The individual error of the estimated Kuroshio water fraction $(r)$ versus potential density in the upper $100 \mathrm{~m}$ of the central South China Sea (SCS). Green lines donate the \pm 0.1 range. Note that the analytical precision of $\mathrm{Ca}^{2+}$ is better than $\pm 5 \mu \mathrm{mol} \mathrm{kg}{ }^{-1}$ (Cao and Dai, 2011), which accounts for less than $2 \%$ of the estimated error.

centrations might have departed from this value due to chemical and/or biological alterations. Here, $N_{\mathrm{K}}$ and $N_{\mathrm{S}}$ are the endmember concentrations of nutrients for the Kuroshio and the SCS proper water at a given isopycnal surface.

\subsection{Model validation and error estimation}

Since the seawater-dissolved calcium ion $\left(\mathrm{Ca}^{2+}\right)$ is nearly conservative in the upper ocean, despite possible small changes resulting from $\mathrm{CaCO}_{3}$ production or dissolution (Cao and Dai, 2011; Feely et al., 2002), we could use the high-precision data of $\mathrm{Ca}^{2+}$ to evaluate the applicability of our isopycnal mixing approach.

As shown in Fig. 7a, the isopycnal mixing approximation worked very well in predicting concentrations of $\mathrm{Ca}^{2+}$ in the upper $100 \mathrm{~m}$ of the central NSCS. The model prediction and the observations were highly correlated $(R=0.993, n=96$, $p<0.0001$ ), and the slope was 0.93 , suggesting a $7 \%$ bulk uncertainty of the model prediction. This provided direct evidence for the applicability of our isopycnal mixing model.

However, observable departures in model prediction from field measurements did exist, which provided an estimate of the errors in the calculated water fractions induced by the physical approximations adopted in the isopycnal mixing model. If $r$ is the error in the derived Kuroshio water fraction $\left(R_{\mathrm{K}}\right)$ and assuming $\mathrm{Ca}^{2+}$ to be perfectly conservative (i.e. the observed $\mathrm{Ca}^{2+}$ is solely a result of water mass mixing without any chemical or biological alterations), we have

$$
\begin{aligned}
& \mathrm{Ca}_{\mathrm{M}}^{2+}=R_{\mathrm{K}} \times \mathrm{Ca}_{\mathrm{K}}^{2+}+\left(1-R_{\mathrm{K}}\right) \times \mathrm{Ca}_{\mathrm{S}}^{2+} \\
& \mathrm{Ca}_{\mathrm{F}}^{2+}=\left(R_{\mathrm{K}}+r\right) \times \mathrm{Ca}_{\mathrm{K}}^{2+}+\left(1-R_{\mathrm{K}}-r\right) \times \mathrm{Ca}_{\mathrm{S}}^{2+} .
\end{aligned}
$$

Here, $\mathrm{Ca}_{\mathrm{M}}^{2+}$ and $\mathrm{Ca}_{\mathrm{F}}^{2+}$ denote the model-derived and fieldobserved $\mathrm{Ca}^{2+}$ concentrations, respectively, and $\mathrm{Ca}_{\mathrm{K}}^{2+}$ and $\mathrm{Ca}_{\mathrm{S}}^{2+}$ are the endmember concentrations of $\mathrm{Ca}^{2+}$ for Kuroshio and SCS proper water, respectively. Therefore, the 
error in each individual estimate of $R_{\mathrm{K}}$ is

$$
r=\frac{\mathrm{Ca}_{\mathrm{M}}^{2+}-\mathrm{Ca}_{\mathrm{F}}^{2+}}{\mathrm{Ca}_{\mathrm{K}}^{2+}-\mathrm{Ca}_{\mathrm{S}}^{2+}} .
$$

As shown in Fig. 7b, the absolute value of $r$ in the upper $100 \mathrm{~m}$ of the central NSCS was mostly $<0.1$, or less than $10 \%$. Statistically, it had a mean value of $-0.02\left(X_{r}\right)$, and a standard deviation of $0.09\left(S_{r}, n=96\right)$. Note that this error $r$ derived from $\mathrm{Ca}^{2+}$ is an upper limit estimate of the model error, as it also includes errors due to potential $\mathrm{CaCO}_{3}$ production or dissolution.

Besides the model approximations, the selection of endmembers also introduced uncertainties. This is detailed in the Supplementary Material. Overall, the uncertainty resulting from the SCS endmember variation was $-0.09 \pm 0.28 \mu \mathrm{mol} \mathrm{L}^{-1}$ (the mean value $\left(X_{\mathrm{NS}}\right)$ \pm standard deviation $\left(S_{\mathrm{NS}}\right)$ is the same in the following descriptions) for $\mathrm{N}+\mathrm{N}, \quad 0.026 \pm 0.015 \mu \mathrm{mol} \mathrm{L}^{-1}$ for $\mathrm{SRP}$ and $0.48 \pm 0.30 \mu \mathrm{mol} \mathrm{L}^{-1}$ for $\mathrm{Si}(\mathrm{OH})_{4}$. On the other hand, the uncertainty induced by the Kuroshio endmember variation was $-0.22 \pm 0.38 \mu \mathrm{mol} \mathrm{L}^{-1}$ for $\mathrm{N}+\mathrm{N}, \quad-0.002 \pm 0.030 \mu \mathrm{mol} \mathrm{L}^{-1}$ for $\mathrm{SRP}$ and $-0.28 \pm 0.59 \mu \mathrm{mol} \mathrm{L}^{-1}$ for $\mathrm{Si}(\mathrm{OH})_{4}$.

Combining the model-induced error $r$ and the uncertainties introduced by the selection of endmembers, the total error for the estimated nutrient concentration (Eq. 3; see Supplementary Material for details) was averaged to be $-0.16 \pm 0.65 \mu \mathrm{mol} \mathrm{L}^{-1}$ for $\mathrm{N}+\mathrm{N}\left(X_{\mathrm{N}} \pm S_{\mathrm{N}}\right)$, $-0.002 \pm 0.043 \mu \mathrm{mol} \mathrm{L}^{-1}$ for SRP and $0.1 \pm 0.73 \mu \mathrm{mol} \mathrm{L}-1$ for $\mathrm{Si}(\mathrm{OH})_{4}$ in the upper $100 \mathrm{~m}$ of the central NSCS. The negative values indicate overestimation of the model.

\subsection{Impact of the Kuroshio intrusion on the nutrient inventory in the central NSCS}

The Kuroshio water fraction $\left(R_{\mathrm{K}}\right.$; Eq. 2$)$ for each water parcel was integrated over the upper $100 \mathrm{~m}$ for a given station to represent the station-integrated Kuroshio water fraction $\left(R_{\mathrm{IKW}}\right)$. Similarly, we calculated the station-integrated Kuroshio nutrient fraction $\left(R_{\mathrm{IKN}}\right)$ according to the following equation:

$R_{\mathrm{IKN}}=\frac{I_{\mathrm{KN}}}{I_{\mathrm{N}}}=\frac{\sum_{z=0}^{z=100 \mathrm{~m}} R_{\mathrm{K}} \times N_{\mathrm{K}}}{\sum_{z=0}^{z=100 \mathrm{~m}}\left(N_{\mathrm{m}}\right)}$,

where $I_{\mathrm{N}}$ is the station-integrated nutrient concentration in the upper $100 \mathrm{~m}$ of the central NSCS, and $I_{\mathrm{KN}}$ is the station-integrated nutrient concentration contributed from the Kuroshio water in the upper $100 \mathrm{~m}$.

As shown in Fig. 8a-d, the spatial distribution of $R_{\mathrm{IKW}}$ displayed distinct features over the seasons. In spring, fall and winter, $R_{\mathrm{IKW}}$ was typically above 0.2 in the northeast part of the central NSCS under the stronger influence of the Kuroshio intrusion (Fig. 8a, c and d). In summer, $R_{\text {IKW }}$ was $<0.2$ except in the region near the Luzon Strait (Fig. 8b). Relative to that in summer, $R_{\mathrm{IKW}}$ in fall was higher in the eastern part $(>0.2)$ while lower in the west $(<0.1)$ (Fig. 8c). Nevertheless, it was clear from the spatial distributions in different seasons that the Kuroshio influence in the central NSCS was persistent all year round, although varying in magnitude.

The distribution patterns of the $R_{\mathrm{IKN}}$ resembled that of $R_{\mathrm{IKW}}$, but the value was much lower. Most notably, only a very small fraction of the Kuroshio water was observed during summer in the central NSCS (Fig. 8b), again suggesting that the Kuroshio did not significantly intrude into the SCS in summer. The basin-wide surface circulation of the SCS in summer (responding to the southwest monsoon) may prevent the Kuroshio from further intrusion (if any) into the interior of the SCS and, instead, it flows out eastwardly through the Luzon Strait (Chu and Li., 2000; Hu et al., 2000; Qu et al., 2000). The lowest seasonal averaged $R_{\mathrm{IKW}}$ was $\sim 0.06$ in summer and the highest seasonal averaged $R_{\mathrm{IKW}}$ was $\sim 0.3$ in spring. The values were $\sim 14 \%$ in fall and $\sim 18 \%$ in winter which showed intermediate values as compared to the former two seasons.

The patchy rather than homogeneous distribution of the $R_{\text {IKW }}$ in the SCS proper was observed (Fig. 8), which might be partly due to the combination of the interior SCS circulation and the Kuroshio intrusion. On the other hand, it should be noted that the estimated Kuroshio water fraction based on the isopycnal mixing model is not necessarily related to instantaneous intruding processes because any formation of a water mass containing fractions of the Kuroshio water may have taken a much longer time than the seasonal timescale.

As shown in Fig. 9a, the model-predicted $\mathrm{N}+\mathrm{N}\left(N_{\mathrm{m}}\right)$ agreed overall well with the field measurements. The fact that the majority of the scattered data points fell outside the estimated $\mathrm{N}+\mathrm{N}$ error $\left(X_{\mathrm{N}} \pm S_{\mathrm{N}}\right)$ domain might suggest significant biological mediation of the nutrient, in particular in the upper layer of the central NSCS (Fig. 9a). As shown in Fig. 9b, the field estimated $\mathrm{N}+\mathrm{N}$ inventory was negatively correlated with the corresponding $R_{\mathrm{IKW}}$. The nearly even distribution of the data points around the theoretical mixing line indicated that the Kuroshio intrusion might play a key role in the $\mathrm{N}+\mathrm{N}$ inventory of the study area.

In order to assess the dilution effect of the Kuroshio intrusion, featured by extremely low nutrients, we calculated the area-integrated Kuroshio dilution amount $\left(K_{\mathrm{NR}}\right)$ of the nutrient inventory over the upper $100 \mathrm{~m}$ of the central NSCS based on the proposed isopycnal mixing model as

$K_{\mathrm{NR}}=\left(\sum_{z=0 \mathrm{~m}}^{\text {area }} \sum_{z=100 \mathrm{~m}}\left(N_{\mathrm{S}}-N_{\mathrm{m}}\right)\right)$.

Here, $N_{\mathrm{S}}$ is the SCS endmember nutrient concentration before Kuroshio dilution, and $N_{\mathrm{m}}$ is the model-predicted 

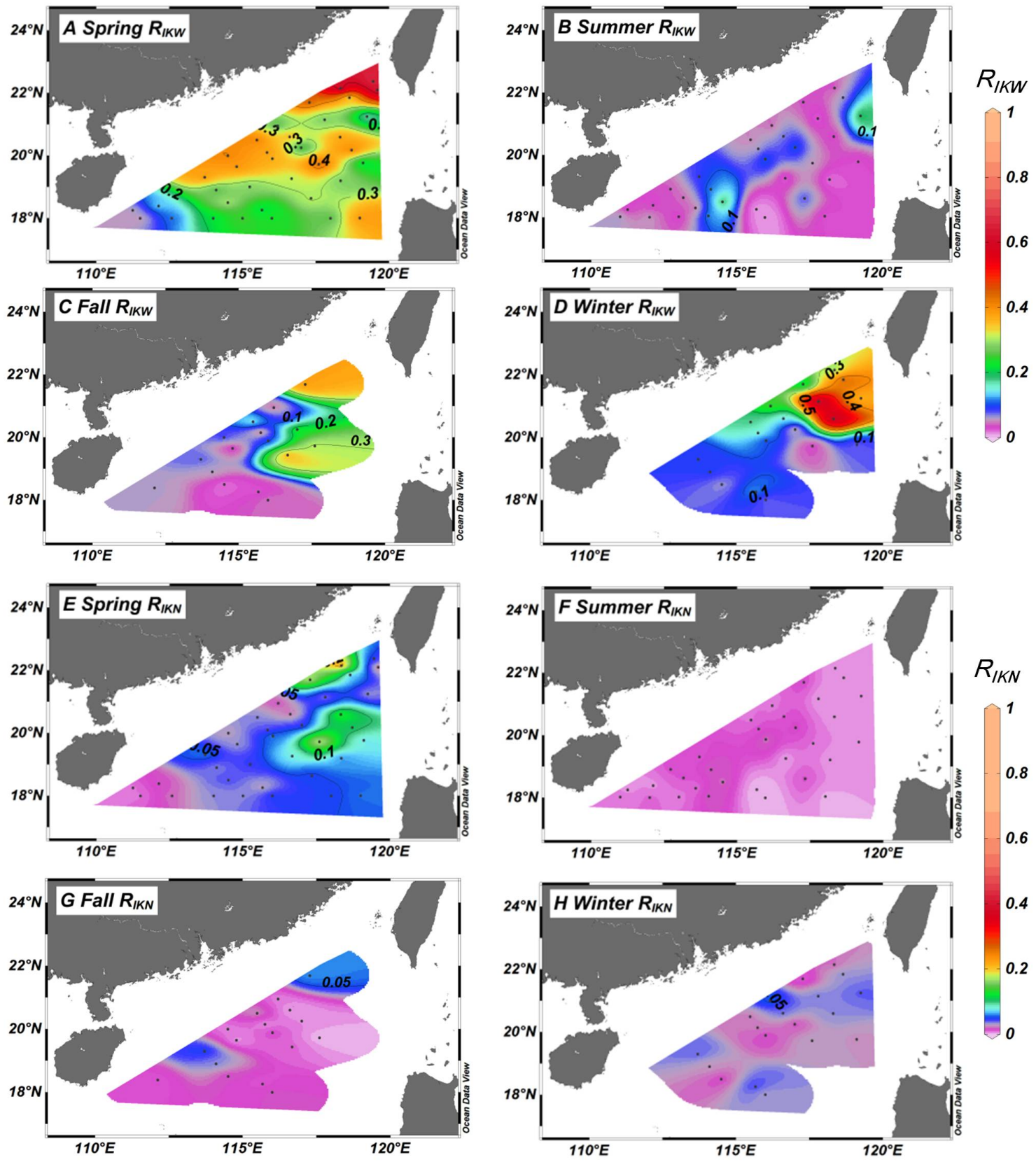

Fig. 8. The station-integrated Kuroshio water fraction $\left(R_{\mathrm{IKW}}, \mathbf{A}-\mathbf{D}\right)$ and nutrient fraction $\left(R_{\mathrm{IKN}}, \mathbf{E}-\mathbf{H}\right)$ in the upper $100 \mathrm{~m}$ of the central northern South China Sea. (A) spring $R_{\mathrm{IKW}} ;(\mathbf{B})$ summer $R_{\mathrm{IKW}} ;(\mathbf{C})$ fall $R_{\mathrm{IKW}} ;(\mathbf{D})$ winter $R_{\mathrm{IKW}} ;(\mathbf{E})$ spring $R_{\mathrm{IKN}} ;(\mathbf{F})$ summer $R_{\mathrm{IKN}} ;(\mathbf{G})$ fall $R_{\mathrm{IKN}}$; and (H) winter $R_{\mathrm{IKN}}$.

nutrient. Assuming that the study area is under steady state on an intra-seasonal timescale, we did a first-order estimate of the nutrient inventory reduction from summer 2009 to winter 2009 . The calculated $K_{\mathrm{NR}}$ values were $\sim 21 \times 10^{9}, \sim 1.5 \times 10^{9}$ and $\sim 22 \times 10^{9} \mathrm{~mol}$ for $\mathrm{N}+\mathrm{N}, \mathrm{SRP}$ and $\mathrm{Si}(\mathrm{OH})_{4}$, respectively. The nutrient inventory reduction in winter 2009 relative to those in summer 2009 were $\sim 25 \times 10^{9}, \sim 3 \times 10^{9}$ and $\sim 60 \times 10^{9} \mathrm{~mol}$ for $\mathrm{N}+\mathrm{N}$, SRP and $\mathrm{Si}(\mathrm{OH})_{4}$, respectively (Table 1 ). As a consequence, the
Kuroshio intrusion accounted for an inventory reduction of $\sim 83, \sim 52$ and $\sim 37 \%$ for $\mathrm{N}+\mathrm{N}, \mathrm{SRP}$ and $\mathrm{Si}(\mathrm{OH})_{4}$ during this period of time, whereas the residual reduction might be attributed to the biological metabolism and/or other physical processes. It should be pointed out that these reduction assessments were referenced to summer 2009, while our four surveys spanned from 2009 to 2011. Therefore, our estimated reduction at seasonal levels assumed no interannual variations in the Kuroshio intrusions into the SCS, which is 

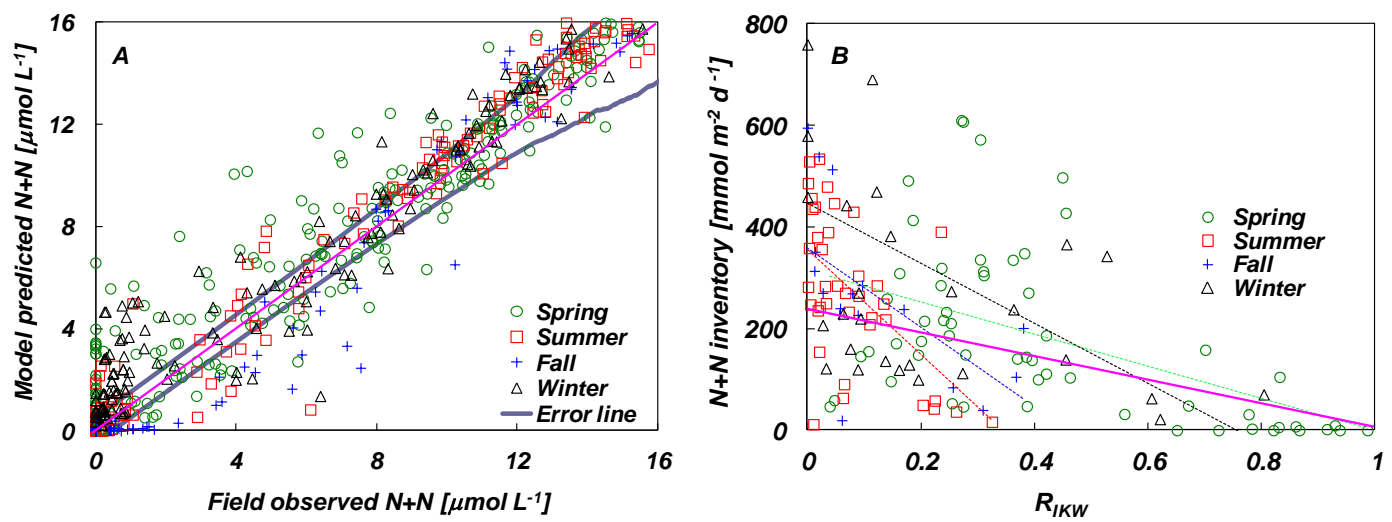

Fig. 9. (A) The model-predicted $\mathrm{N}+\mathrm{N}$ concentrations versus the field measurements in the upper $100 \mathrm{~m}$ of the central northern South China Sea (NSCS). Pink line is the 1:1 line while gray lines donate the $X_{r} \pm S_{r}$ domain; (B) The relationship between the field observed N $+\mathrm{N}$ inventory and the station-integrated Kuroshio water fraction $\left(R_{\mathrm{IKW}}\right)$. The solid pink line is the theoretical mixing line constructed by the $\mathrm{N}+\mathrm{N}$ inventory of the SCS and Kuroshio endmembers $\left(\sim 250 \mathrm{mmol} \mathrm{m}^{-2}\right.$ in NSCS and $\sim 5 \mathrm{mmol} \mathrm{m}^{-2}$ in Kuroshio, respectively, which is obtained by supposing the mixing $R_{\mathrm{KW}}$ is the same value in the entire upper $100 \mathrm{~m}$ ). The dotted lines with the different colors represent the corresponding linear regressions from different seasons.

however not always true (e.g. Chao et al., 1996; Michael et al., 2006; Liu et al., 2011).

It might be argued that other processes also regulate the $\mathrm{N}+\mathrm{N}$ inventory in the upper ocean. One additional possible process to supply nutrients is $\mathrm{N}_{2}$-fixation. However, $\mathrm{N}_{2}$-fixation was estimated to be $\sim 20 \mathrm{mmol} \mathrm{N} \mathrm{m}{ }^{-2} \mathrm{yr}^{-1}$ in the NSCS (Kao et al., 2012), which only accounts for less than $10 \%$ of the present nutrient inventory variation $\left(\sim 250 \mathrm{mmol} \mathrm{m}^{-2}\right)$. Moreover, $\mathrm{N}_{2}$-fixation is a net source for the $\mathrm{N}+\mathrm{N}$ inventory which accounts for the increase in the $\mathrm{N}+\mathrm{N}$ inventory, while the reduction in the nutrient inventory we observed occurred in the second half of 2009. Thus, the genuine inventory reduction might exceed our estimation. Another possible process to add nutrients is diapycnal mixing. In particular, during the strong northeast monsoon season, deepening of the surface mixed layer frequently occurs, which enhances the influxes of the nutrient-rich subsurface water (Tseng et al., 2005; Liu et al., 2002). As a result, an enhancement by $\sim 2$ fold in primary production in the central NSCS was reported in winter as compared to that in summer (Chen, 2005; Chen and Chen, 2006). However, based on turbulence profiling measurements (data not shown), we estimated the upward $\mathrm{N}+\mathrm{N}$ flux across the $100 \mathrm{~m}$ layer to be $\sim 0.1 \mathrm{mmol} \mathrm{m}^{-2} \mathrm{~d}^{-1}$, implying that it might take more than $\sim 7 \mathrm{yr}$ to thoroughly change the $\mathrm{N}+\mathrm{N}$ inventory given the averaged $\mathrm{N}+\mathrm{N}$ inventory of $\sim 250 \mathrm{mmol} \mathrm{m}^{-2}$ in the upper $100 \mathrm{~m}$ of the central NSCS. Therefore, we contend that on a seasonal timescale, the effect of diapycnal mixing on the $\mathrm{N}+\mathrm{N}$ inventory might be negligible.

At seasonal timescale, variations of the isopycnal depth can also change the nutrient inventory in the upper $100 \mathrm{~m}$ water column. The overall positive correlation between the density and nutrient concentration observed in the upper ocean suggests that any lift of the isopycnal would induce increase in nutrient inventory in the upper water column. As a matter of fact, this is exactly the reason why we observed a very scattered relationship between the station-integrated Kuroshio $\left(R_{\mathrm{IKW}}\right)$ water fraction and the nutrient inventory as shown in Fig. 9b. Such impact can also be seen at the seasonal timescale reflected in the different slopes in Fig. 9b.

The drivers causing the variations of isopycnal depth can be beyond the Kuroshio intrusion. For example, both mesoscale eddies and basin-scale Ekman convergence/divergence may induce such variations of the isopycnal depth. The impact of the mesoscale eddies on isopycnal depth/nutrient inventory could be significant in the northeast SCS during winter (Fig. 5d), when we observed a low nutrient inventory center that might not only reflect the Kuroshio intrusion but also a warm eddy. During our spring cruise (Fig. 5a), the high nutrient inventory center in the central NSCS (corresponding to the isopycnal uplift) should be attributable to the basin-scale divergence. We are aware that both mesoscale eddies and basin-scale convergence/divergence may have induced the scattered relationship and different slopes between the observed nutrient inventory and the $R_{\mathrm{IKW}}$ as shown in Fig. $9 \mathrm{~b}$. However, their effect on the nutrient inventory will vanish when the isopycnal returns to its initial position, after for example the decay of the eddy and/or the basin-scale circulation is weakened. Thus, we believe that the Kuroshio intrusion should play a dominant role in determining the nutrient inventory distribution in the NSCS.

The Kuroshio intrusion might also affect the nutrient ratio stoichiometry in the central NSCS, due to the different $\mathrm{Si} / \mathrm{N}$ and N/P ratios between the SCS proper and the Kuroshio water at the same isopycnal surface. Potentially attributable to $\mathrm{N}_{2}$-fixation (e.g. Kao et al., 2012) and upwelling (Gong et al., 1992), the N/P ratio of the upper $100 \mathrm{~m}$ ranged $0.2-14.5$ in 

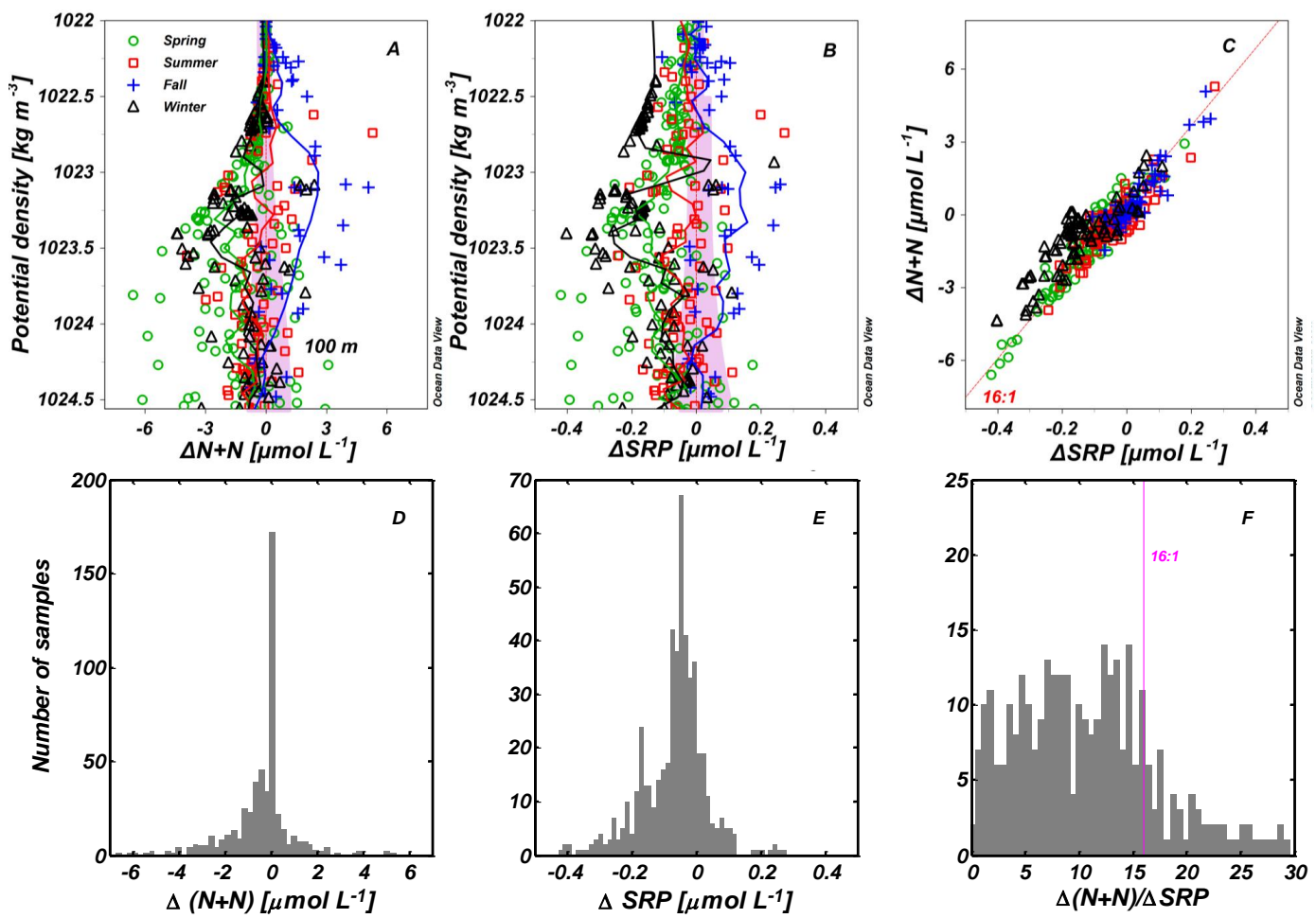

Fig. 10. $\Delta(\mathrm{N}+\mathrm{N})(\mathbf{A})$ and $\Delta \mathrm{SRP}$ (B) versus potential density in the upper $100 \mathrm{~m}$ of the central NSCS. (C) The relationship between $\Delta(\mathrm{N}+\mathrm{N})$ and $\Delta$ SRP. Lines in $(\mathbf{A})$ and $(\mathbf{B})$ represent the moving average during each season. Pink shadows in (A) and (B) indicate the $X_{\mathrm{N}} \pm S_{\mathrm{N}}$ domain (see Supplementary for details). The straight pink line in (C) denotes the theoretical correlation of $16: 1$ based on the Redfield ratio (Redfield et al., 1963). Also shown are the histogram distributions of $\Delta(\mathrm{N}+\mathrm{N})(\mathbf{D}), \Delta \mathrm{SRP}(\mathbf{E})$ and $\Delta(\mathrm{N}+\mathrm{N}) / \Delta \mathrm{SRP}(\mathbf{F})$ in the upper $100 \mathrm{~m}$ of the central NSCS.

the SCS, which is generally higher than that in the Kuroshio of $0.1-10$ in the upper $150 \mathrm{~m}$. The intrusion of the Kuroshio and its seasonal contrast might therefore significantly shape the nutrient ratio structure in the SCS, which would have a fundamental impact on the ecosystem structure therein.

\subsection{Biogeochemical alteration of nutrients in the upper $100 \mathrm{~m}$ of the central NSCS}

Although the model-predicted $\mathrm{N}+\mathrm{N}$ concentrations and the field measurements showed an overall agreement in the upper $100 \mathrm{~m}$ of the central NSCS, observable departures did exist (Figs. 9a and 10). The difference, denoted here as $\Delta$ (field observation minus the model prediction), would suggest a biogeochemically mediated portion of the nutrients. As shown in Fig. 10a, the majority of the departures occurred in the upper euphotic zone where $\mathrm{N}+\mathrm{N}$ concentrations were lower than $10 \mu \mathrm{mol} \mathrm{L}^{-1}$.

For $\Delta(\mathrm{N}+\mathrm{N})$ and $\Delta \mathrm{SRP}$, a scatter distribution ranging from -6 to $6 \mu \mathrm{mol} \mathrm{L}-1$ and -0.4 to $0.3 \mu \mathrm{mol} \mathrm{L}^{-1}$ were found in the upper $100 \mathrm{~m}$ of the central NSCS (Fig. 10a, b). The histogram distributions further showed that the majority of these $\Delta$ data was grouped at $\pm 2 \mu \mathrm{mol} \mathrm{L}^{-1}$ for $\Delta(\mathrm{N}+\mathrm{N})$ and $\pm 0.15 \mu \mathrm{mol} \mathrm{L}^{-1}$ for $\Delta \mathrm{SRP}(90 \%$ data range; Fig. $10 \mathrm{~d}$, e). As shown by the seasonal moving average lines, both $\Delta(\mathrm{N}+\mathrm{N})$ and $\triangle$ SRP values were negative in spring and winter but positive in fall (Fig. 10a, b). We inferred that on average $\sim 0$ $3 \mu \mathrm{mol} \mathrm{L}{ }^{-1}$ of $\mathrm{N}+\mathrm{N}$ and $\sim 0-0.15 \mu \mathrm{mol} \mathrm{L}^{-1}$ of SRP were removed by biological metabolism in the upper $100 \mathrm{~m}$ of central NSCS during winter and spring. Such removal was much more significant in the upper $50 \mathrm{~m}$ in winter, which agreed well with the fact that the primary production is generally higher in winter in the NSCS (Chen, 2005; Chen and Chen, 2006). In summer, both $\Delta(\mathrm{N}+\mathrm{N})$ and $\Delta \mathrm{SRP}$ were around zero, suggesting no significant biological consumption of nutrients. In contrast, in fall, $\Delta(\mathrm{N}+\mathrm{N})$ and $\Delta \mathrm{SRP}$ were overall positive suggesting net nutrient addition in the upper central NSCS.

If we further assumed that our study area was under steady state on a seasonal timescale, the above removal of nutrients would be translated into a new production of about $6.0 \pm 2.7 \mathrm{mmol} \mathrm{C} \mathrm{m}^{-2} \mathrm{~d}^{-1}$ in spring, $1.8 \pm 2.7 \mathrm{mmol}$ $\mathrm{C} \mathrm{m}^{-2} \mathrm{~d}^{-1}$ in summer, $-4.5 \pm 2.7 \mathrm{mmol} \mathrm{C} \mathrm{m}^{-2} \mathrm{~d}^{-1}$ in fall and $7.4 \pm 2.7 \mathrm{mmol} \mathrm{C} \mathrm{m}^{-2} \mathrm{~d}^{-1}$ in winter based on the $\mathrm{C} / \mathrm{N}$ Redfield ratio of 106/16 (Redfield et al., 1963). The positive value in fall might indicate that nutrient addition was larger than its removal, inducing no net production. 
It should be pointed out that the above-derived new production values in spring and summer were very close to those previously reported in the NSCS basin $(\sim 5.8 \mathrm{mmol}$ $\mathrm{C} \mathrm{m}^{-2} \mathrm{~d}^{-1}$ in spring, $\sim 2.5 \mathrm{mmol} \mathrm{C} \mathrm{m}^{-2} \mathrm{~d}^{-1}$ in summer), based on the ${ }^{15} \mathrm{~N}$ incubation method (Chen, 2005). However, our derived value in winter was substantially lower than the reported value of $\sim 21.7 \mathrm{mmol} \mathrm{C} \mathrm{m}^{-2} \mathrm{~d}^{-1}$ (Chen, 2005), and our derived data in fall was significantly different from the reported value of $\sim 4.1 \mathrm{mmol} \mathrm{C} \mathrm{m}^{-2} \mathrm{~d}^{-1}$. The reasons for the discrepancy in the fall and winter of the new production estimates are unclear and require additional studies. We also note that the field measurements in winter have been extremely sparse in the SCS as elsewhere in the world ocean.

Nevertheless, our derived $\Delta(\mathrm{N}+\mathrm{N}) / \Delta \mathrm{SRP}$ ratio, or the relative biological consumption, with its average value of $\sim 12.8$ was in very good agreement with the Redfield Ratio (Redfield et al., 1963) (Fig. 10c, f). This ratio was also consistent with the $(\mathrm{N}+\mathrm{N}) / \mathrm{SRP}$ ratio obtained from the depths in the SCS, the average of which was around 13.6 based on the long-term observations at SEATS (Wong et al., 2007). Such consistence provided another piece of evidence that our isopycnal mixing model was generally in order. Among different seasons, the $\Delta(\mathrm{N}+\mathrm{N}) / \Delta$ SRP ratio diagnosed from the model, which was the slope of the linear regression line between $\Delta(\mathrm{N}+\mathrm{N})$ and $\Delta \mathrm{SRP}$, was highest in fall $(\sim 17.8, R=0.97, n=66, P<0.0001)$, but lowest in winter $(\sim 9.2, R=0.79, n=88, P<0.0001)$. This ratio was $\sim 13.4$ in spring $(R=0.93, n=168, P<0.0001)$ and $\sim 12.4$ in summer $(R=0.88, n=135, P<0.0001)$, both of which were close to the average value of $\sim 12.8$. Quigg et al. (2003) reported a different phytoplankton composition associated with different element composition, and so a different $\Delta(\mathrm{N}+\mathrm{N}) / \Delta$ SRP addition/removal ratio in the NSCS might indicate that a red superfamily (lower $\mathrm{N} / \mathrm{P}$ ratio demand) was prevailing in winter and a green superfamily (high $\mathrm{N} / \mathrm{P}$ ratio demand) in fall.

\section{Conclusions}

Both nutrient concentrations and their inventories in the upper $100 \mathrm{~m}$ of the central NSCS displayed significant spatial and seasonal variations. The inventories were overall higher in the west part relative to the east part of the central NSCS, which was consistent with the decreasing dilution effect along the travel path of the Kuroshio intrusion. On seasonal timescale, the nutrient inventories in the upper $100 \mathrm{~m}$ were relatively high in summer but low in spring and winter. In addition to the diapycnal mixing, $\mathrm{N}_{2}$-fixation, mesoscale eddies and basin-scale divergence/convergence, the Kuroshio intrusion might therefore play a dominant role in determining the nutrient inventory distribution in the central NSCS.

A two endmember based isopycnal mixing model was adopted to derive the Kuroshio and SCS proper water fractions in the water parcel of the central NSCS, and this indi- cated that spring and winter were the two main seasons for the Kuroshio water fraction distribution in the central NSCS. The station-integrated Kuroshio water fraction showed a significant negative correlation with the nutrient inventory in the upper $100 \mathrm{~m}$ of the central NSCS, indicating the dominant Kuroshio dilution effect. Based on the endmember sensitivity analysis and water fraction error estimation, our wellvalidated model results demonstrated relatively high nutrient consumption during winter and spring but possibly net addition in fall in the upper $100 \mathrm{~m}$ of the central NSCS.

It is important to note that the SCS does not have its own independent water mass formation since, on a timescale $>4 \mathrm{yr}$ longer than the residence time of the SCS surface water (Chen, 2001), the SCS water originally comes from the wNP, although with a certain degree of transformation. We thus caution applying the isopycnal mixing approach to quantify the impact of the Kuroshio intrusion into the SCS on a longer timescale, when diapycnal mixing processes would become significant.

\section{Supplementary material related to this article is available online at http://www.biogeosciences.net/10/ 6419/2013/bg-10-6419-2013-supplement.pdf.}

Acknowledgements. This study was funded by the National Basic Research Program of China (973 Program) through grant No. 2009CB421200 and by the National Natural Science Foundation of China through grants No. 41130857, 41121091 and 41023007. We are grateful to the captain and crew members on R/V Dongfanghong II as well as H. Lin, X. Huang, Y. Xu, J. Lin and A. Han for their assistance in sampling and/or analyses during the cruises. We thank K.-K. Liu, T.-D. Qu, C. Measure, P. Cai, Y. Li, H. Lin, H. Gupta and G. Wang for their valuable suggestions. J. Hodgkiss is thanked for his help with the English.

Edited by: H. Liu

\section{References}

Baringer, M. O. and Price, J. F.: A review of the physical oceanography of the Mediterranean outflow, Mar Geol., 155, 63-82, 1999.

Bourgault, D., Hamel, C., Cyr, F., Tremblay, J.É., Galbraith, P.S., Dumont, D., and Gratton, Y.: Turbulent nitrate fluxes in the Amundsen Gulf during ice-covered conditions, Geophys. Res. Lett., 38, L15602, doi:10.1029/2011GL047936, 2011.

Cai, W. J., Dai, M. H., Wang, Y. C., Zhai, W. D., Huang, T., Chen, S. T., Zhang, F., Chen, Z. Z., and Wang, Z. H.: The biogeochemistry of inorganic carbon and nutrients in the Pearl River estuary and the adjacent Northern South China Sea, Cont. Shelf Res., 24, 1301-1319, 2004.

Cao, Z. M. and Dai, M. H.: Shallow-depth $\mathrm{CaCO}_{3}$ dissolution: Evidence from excess calcium in the South China Sea and its export to the Pacific Ocean, Global Biogeochem. Cy., 25, GB2019, doi:10.1029/2009GB003690, 2011. 
Centurioni, L. R., Niiler, P. P., and Lee, D. K.: Observations of Inflow of Philippine Sea Surface Water into the South China Sea through the Luzon Strait, J. Phys. Oceanogr., 34, 113-121, 2004.

Chao, S. Y., Shaw, P. T., and Wu, S. Y..: El Niño modulation of the South China Sea circulation, Prog. Oceanogr., 38, 51-93, doi:10.1016/S0079-6611(96)00010-9, 1996.

Chen, C. T. A., and Huang, M. H.: A mid-depth front separating the South China Sea water and the West Philippine Sea water, J. Oceanogr., 52, 17-25, 1996.

Chen, C. T. A., Wang, S. L., Wang, B. J., and Pai, S. C.: Nutrient budgets for the South China Sea basin, Mar. Chem., 75, 281-300, 2001.

Chen, Y. L.: Spatial and seasonal variations of nitrate-based new production and primary production in the South China Sea, Deep Sea Res I., 52, 319-340, 2005.

Chen, Y. L. and Chen, H. Y.: Seasonal dynamics of primary and new production in the northern South China Sea: The significance of river discharge and nutrient advection, Deep Sea Res I., 53, 971986, 2006.

Chen, Y. L., Chen, H. Y., Tuo, S., and Ohki, K.: Seasonal dynamics of new production from Trichodesmium $\mathrm{N}_{2}$ fixation and nitrate uptake in the upstream Kuroshio and South China Sea basin, Limnol. Oceanogr., 53, 1705-1721, 2008.

Chu, P. C. and Li, R. F.: South China Sea Isopycnal-Surface Circulation, J. Phys. Oceanogr., 30, 2419-2438, 2000.

Dai, M., Meng, F., Tang, T., Kao, S.-J., Lin, J., Chen, J., Huang, J.-C., Tian, J., Gan, J., and Yang, S.: Excess total organic carbon in the intermediate water of the South China Sea and its export to the North Pacific, Geochem. Geophys. Geosyst., 10, Q12002, doi:10.1029/2009GC002752, 2009.

Fang, G. H., Wang, Y. G., Wei, Z. X., Fang, Y., Qiao, F. L., and Hu, X. M.: Interocean circulation and heat and freshwater budgets of the South China Sea based on a numerical model, Dynam. Atmos. Oceans., 47, 55-72, 2009.

Feely, R. A., Sabine, C.L., Lee, K., Millero, F. J., Lamb, M. F., Greeley, D., Bullister, J. L., Key, R. M., Peng, T. H., Kozyr, A., Ono, T., and Wong, C. S.: In situ calcium carbonate dissolution in the Pacific Ocean, Global Biogeochem. Cy., 16, 1144, doi:10.1029/2002GB001866, 2002.

Glover, D. M., Jenkins, W. J., and Doney, S. C.: Modeling methods for marine science, Cambridge University Press, pp. 255, 2005.

Gong, G. C., Liu, K. K., Liu, C. T., and Pai, S. C.: The chemical hydrography of the South China Sea west of Luzon and a comparison with the West Philippine Sea, Terr. Atmos. Ocean. Sci., 3, 587-602, 1992.

Gordon, A. L.: Circulation of the Caribbean Sea, J. Geophys. Res., 72, 6207-6223, 1967.

Han, A. Q., Dai, M. H., Kao, S. J., Gan, J. P., Li, Q., Wang, L. F., Zhai, W. D., and Wang, L.: Nutrient dynamics and biological consumption in a large continental shelf system under the influence of both a river plume and coastal upwelling, Limnol. Oceanogr., 57, 486-502, doi:10.4319/lo.2012.57.2.0486, 2012.

Hu, J. Y., Kawamura, H., Hong, H. S., and Qi, Y. Q.: A Review on the Currents in the South China Sea: seasonal Circulation, South China Sea Warm Current and Kuroshio Intrusion, J. Oceanogr., 56, 607-624, 2000.

Huertas, I. E., Ríos, A.F., García-Lafuente, J., Navarro, G., Makaoui, A., Sánchez-Román, A., Rodriguez-Galvez, S., Orbi, A., Ruíz, J., and Pérez, F. F.: Atlantic forcing of the Mediter- ranean oligotrophy, Global Biogeochem. Cy., 26, GB2022, doi:10.1029/2011GB004167, 2012.

Kao, S. J., Yang, J. Y. T., Liu, K. K., Dai, M. H., Chou, W. C., Lin, H. L., and Ren, H.: Isotope constraints on particulate nitrogen source and dynamics in the upper water column of the oligotrophic South China Sea, Global Biogeochem. Cy., 26, GB2033, doi:10.1029/2011GB004091, 2012.

Kara, A. B., Rochford, P. A., and Hurlburt, H. E.: An optimal definition for ocean mixed layer depth, J. Geophys. Res., 105, 1680316821, doi:10.1029/2000JC900072, 2000.

Kida, S., Yang, J. Y., and Price, J. F.: Marginal Sea Overflows and the Upper Ocean Interaction, J. Phys. Oceanogr., 39, 387-403, doi:10.1175/2008JPO3934.1, 2009.

Lewis, M. R., Harrison, W. G., Oakey, N. S., Hebert, D., and Platt, T.: Vertical Nitrate Fluxes in the Oligotrophic, Science, 234, 4778, 870-873, 1986.

Liang, W. D., Yang, Y. J., Tang, T. Y., and Chuang, W. S.: Kuroshio in the Luzon Strait, J. Geophys. Res., 113, C08048, doi:10.1029/2007JC004609, 2008.

Lin, Z. H., Mo, X. G., Li, H. X., and Li, H. B.: Comparison of three spatial interpolation methods for climate variables in China, Acta Geographica Sinica, 57, 47-56, 2002.

Liu, K. K., Chao, S. Y., Shaw, P. T., Gong, G. C., Chen, C. C., and Tang, T. Y.: Monsoon-forced chlorophyll distribution and primary production in the South China Sea: observations and a numerical study, Deep Sea Res. I., 49, 1387-1412, 2002.

Liu, Q. Y., Feng, M., and Wang, D. X.: ENSO-induced interannual variability in the southeastern South China Sea, J. Oceanogr., 67,127-133, doi:10.1007/s10872-011-0002-y, 2011.

Liu, Z. Y. and Lozovatsky, I. D.: Upper pycnocline turbulence in the northern South China Sea, Chinese Sci. Bull., 57, 2302-2306, 2012.

Ma, J., Yuan, D. X., and Liang, Y.: Sequential injection analysis of nanomolar soluble reactive phosphorus in seawater with HLB solid phase extraction, Mar. Chem., 111, 151-159, doi:10.1016/j.marchem.2008.04.011, 2008.

Michael, J. C., Glen, G. G., and Robert, C. B.: Interannual Variability of the Kuroshio Intrusion in the South China Sea, J. Oceanogr., 62, 559-575, doi:10.1007/s10872-006-0076-0, 2006.

Matsuno, T., Lee, J.-S., and Yanao, S.: The Kuroshio exchange with the South and East China Seas, Ocean Sci., 5, 303-312, doi:10.5194/os-5-303-2009, 2009.

Pratt,L. J. and Spall, M. A.: Circulation and Exchange in Choked Marginal Seas, J. Phys. Oceanogr., 38, 2639-2661, doi:10.1175/2008JPO3946.1, 2008.

Qu, T. D.: Upper-Layer Circulation in the South China Sea, J. Phys. Oceanogr., 30, 1450-1460, 1999.

Qu, T. D., Mitsudera, H., and Yamagata, T.: Intrusion of the North Pacific waters into the South China Sea, J. Geophys. Res., 105, 6415-6424, 2000.

Quigg, A., Finkel, Z. V., Irwin, A. J., Rosenthal, Y., Ho, T. Y., Reinfelder, J. R., Schofield, O., Morel, F. M. M., and Falkowski, P. G.: The evolutionary inheritance of elemental stoichiometry in marine phytoplankton, Nature, 425, 291-294, 2003.

Redfield, A. C., Ketchum, B. H., and Richards, F. A.: The influence of organisms on the composition of seawater, in: The Sea, edited by: Hill, M. N., Wiley, New York, 26-77, 1963. 
Shaw, P. T.: The seasonal variation of the intrusion of the Philippine Sea water into the South China Sea, J. Geophys. Res., 96, 821827, doi:10.1029/90JC02367, 1991.

Thingstad, T. F., Krom, M. D., Mantoura, R. F. C., Flaten, G. A. F., Groom, S., Herut, B., Kress, N., C. Law, S., Pasternak, A., Pitta, P., Psarra, S., Rassoulzadegan, F., Tanaka, T., Tselepides, A., Wassmann, P., Woodward, E.M.S., Wexels Riser, C., Zodiatis, G., and Zohary, T.: Nature of Phosphorus Limitation in the Ultraoligotrophic Eastern Mediterranean, Science, 309, 10681071, 2005.

Tian, J. W., Yang, Q. X., Liang, X. F., Xie, L.L., Hu, D. X., Wang, F., and Qu, T. D.: Observation of Luzon Strait transport, Geophys. Res. Lett., 33, L19607, doi:10.1029/2006GL026272, 2006.

Tian, J. W., Yang, Q. X., and Zhao, W.: Enhanced Diapycnal Mixing in the South China Sea, J. Phys. Oceanogr., 39, 3191-3203, doi:10.1175/2009JPO3899.1, 2009.
Tseng, C. M., Wong, G. T. F., Lin, I. I., Wu, C. R., and Liu, K. K.: A unique seasonal pattern in phytoplankton biomass in low-latitude waters in the South China Sea, Geophys. Res. Lett., 32, L08608, doi:10.1029/2004GL022111, 2005.

Tseng, C. M., Wong, G. T. F., Chou, W. C., Lee, B. S., Sheu, D. D., and Liu, K. K.: Temporal variations in the carbonate system in the upper layer at the SEATS station, Deep Sea Res. II, 54, 1448-1468, doi:10.1016/j.dsr2.2007.05.003, 2007.

Wong, G. T. F., Tseng, C. M., Wen, L. S., and Chung, S. W.: Nutrient dynamics and N-anomaly at the SEATS station, Deep Sea Res II., 54, 1528-1545, doi:10.1016/j.dsr2.2007.05.011, 2007.

Wu, J. F., Chung, S. W., Wen, L. S., Liu, K. K., Chen, Y. L., Chen, H. Y., and Karl, D. M.: Dissolved inorganic phosphorus, dissolved iron, and Trichodesmium in the oligotrophic South China Sea, Global Biogeochem. Cy., 17, 1008, doi:10.1029/2002GB001924, 2003. 